Marcin Śrama

(Poznań)

https://orcid.org/0000-0001-9705-298X

\title{
UWIĘZIONY MASON, NATAN MĘDRZEC I INKOWIE, CZYLI RZECZ O SZTUCE PEWNEGO NIEMIECKIEGO BARONA W KONTEKŚCIE OŚWIECENIOWEJ IDEI TOLERANCJI
}

\begin{abstract}
This paper discusses the drama entitled "Le franc-maçon prisonnier", whose French-language version written by Hans Heinrich Freiherr von Ecker und Eckhoffen was published in 1777, (the longer German version, i.e. Der Freymaurer im Gefängnis, signed Hans Karl Freiherr von Ecker und Eckhoffen followed a year later), in the context of the Enlightenment concept of tolerance, and the Freemasonic and literary activity of the brothers (co-authors, or the author and the translator of the work). The issues relating to the piece and the literary work of the von Ecker und Eckhoffens has not been previously addressed in any publications in Polish.
\end{abstract}

\section{Keywords}

oświecenie, dramat, wolnomularstwo, tolerancja

Odkąd John Locke w roku 1689 wydał poświęcony tolerancji traktat filozoficzny, w którym wykazywał, iż jest ona nie tylko zgodna z zasadami chrześcijaństwa, ale że jest wartością wynikającą z Ewangelii ${ }^{1}$, oświecenie przyczyniało się do szerzenia tej idei jako źródła postawy poszanowania wobec różnych od naszych przekonań religijnych (z czasem ogólniej: światopoglądowych)². W ślady angielskiego myśliciela poszli przedstawiciele oświecenia francuskiego i niemieckiego. Szcze-

\footnotetext{
1 Locke 1963.

2 Zob. Szwed 2014, s. 65-85.
} 
gólną rolę odegrał w jej popularyzowaniu Wolter, który opublikował w roku 1763 swój „Traktat o tolerancji” jako wyraz sprzeciwu wobec wykonania rok wcześniej egzekucji protestanta Jeana Calasa, w którego obronę był zaangażowany osobiście. Opisawszy tę postawę jako wynikającą z chrześcijańskiej idei miłosierdzia, ukazywał jednocześnie sprzeczność „pomiędzy głoszoną nauką a praktyką wymuszania nawróceń w Kościele”3. Francuski filozof w późniejszym czasie angażował się także w kolejne procesy o bluźnierstwo: La Barre’a, Montbailliego oraz Pierre-Paula Sirvena. W tej ostatniej sprawie podejmował próby uzyskania wsparcia ze strony Stanisława Augusta Poniatowskiego ${ }^{4}$.

W przypominanym tu procesie dowartościowywania idei i postawy tolerancji ważną rolę odgrywał także dramat. Najczęściej przywoływany jako przykład jest wydany w roku 1779 dramat Gottholda Ephraima Lessinga „Natan mędrzec” ze względu na opowieść o trzech pierścieniach przedstawioną Saladynowi przez mądrego Żyda:

Niegdyś, przed laty, na dalekim wschodzie

Żył mąż, co pierścień cenny z drogiej ręki

Otrzymał. Opal igrał w tym pierścieniu

Barw tysiącami i miał moc tajemną,

Że czynił tego, kto go nosił ufnie,

Bogu i ludziom miłym. (...)

W ten sposób, że ten pierścień drogi złożył,

Ze wszystkich synów najukochańszemu,

I że mu zlecił, by po swoim zgonie,

Znów dał go temu z synów, dla którego

Największa miłość będzie miat, tak, aby

Najulubieńszy, bez żadnego względu

$\mathrm{Na}$ kolej rodu, tylko na podstawie

Pierścienia, głową byt i księciem domu...

[...]

Tak pierścień ciągle z syna szedł na syna,

Aż go trzech synów ojciec odziedziczył,

Który jednako kochał ich i którzy

Jednako wzajem go kochali. Czasem

Ten mu się zdawał, czasem znowu inny,

W miarę jak z którym bawił, gdy dwaj drudzy

Byli od serca jego oddaleni,

Godnym pierścienia i przez słabość, której

Źródło $w$ miłości było, przyobiecat

Pierścień każdemu. Póki żył, nie było

Żadnych stąd skutków, lecz gdy umrzeć przyszło,

${ }^{3}$ Majkowski 1998, s. 43. Wolter 1988.

${ }^{4}$ Siemieński 1876, s. 43. 
Ojciec w kłopocie znalazł się niemałym.

Przykro mu było zmartwić tych dwóch synów,

Którzy na jego polegali słowie...

Cóż robić? Posłał skrycie do złotnika,

Kazał mu zrobić dwa pierścienie nowe

Na wzór pierwszego, kosztów ani trudu

Nie szczędząc. Złotnik spełnił polecenie

I gdy robotę odniósł, sam właściciel

Nie mógł rozpoznać, który był prawdziwy

Wśród trzech pierścieni. Więc zawołał synów,

Mówił osobno z każdym i każdemu

Dał pierścień jeden i błogosławieństwo,

A potem umarł...

[...] łatwo zgadnąć, co się potem stało...

Zaledwie ojciec umarł, każdy przyszedł

Ze swym pierścieniem, chcąc być panem domu...

Zaczęli badać, skarżyć się i spierać...

Daremnie!... Dowieść, który z trzech pierścieni

Prawdziwy, było już niepodobieństwem,

Prawie zupełnie takim, jakim dla nas

Powiedzieć, która wiara jest prawdziwą ${ }^{5}$.

Opowieść ta stanowi komentarz do skontrastowanego przedstawienia w sztuce dwóch grup bohaterów i motywacji ich postaw - z jednej strony chrześcijańskiego patriarchy Jerozolimy i wielkiego mistrza templariuszy jako ludzi niesprawiedliwych, dla których najważniejszy jest zapis prawa dotyczący zakazu konwersji z katolicyzmu na inną religię, w imię którego są w gotowi skazać na śmierć niewinnego człowieka, tytułowego Natana, tylko dlatego, że wychował on w religii żydowskiej uratowane przez siebie dziecko i traktował je jak własne, a z drugiej - Saladyna, jego siostry i mędrca jako bohaterów pozytywnych, co w sposób jednoznaczny miało unaocznić odbiorcom, że większe znaczenie dla oceny moralnej postępowania człowieka od wierności wyznawanej religii, jej dogmatów i skuteczności w ewangelizowaniu prowadzonym często z pomocą miecza, ma dobro, które człowiek czyni ${ }^{6}$. W sposób oczywisty Lessing nawiązuje tu do oświeceniowej religii naturalnej jako takiej, która zawiera w sobie zalecenia moralne wspólne dla wszystkich religii pozytywnych, czyli koncepcji głoszonej między innymi przez masonerię, do której należał, wobec czego przywołany dramat może być uznawany za manifest wolnomularski ${ }^{\top}$.

${ }^{5}$ Lesssing 1877, s. 85-87 [wyróżnienia M.Ś.].

${ }^{6}$ Kluge i Świderska 2010, s. 63-64.

7 Tezę tę jako pierwsi podnieśli niemieccy literaturoznawcy w II połowie XIX wieku (Lindemann 1866), za nimi: Zdziechowski 1938, s. 37-38, z nowszych badaczy Maria Wawrykowa: Wawrykowa 1989, s. 82; eadem 1993, s. 19-24, por. Rostworowski 1984, s. 426-427. 
Poglądy takie w wieku XVIII były jednak przyjmowane niechętnie, a czasem wręcz wrogo, zarówno przez Kościół katolicki uznający je za przejaw indyferentyzmu religijnego ${ }^{8}$, jak i władze w krajach katolickich, które widziały w masonerii nie tylko zagrożenie dla stabilności państwa z powodu zacierania podziałów stanowych, na których się ono wspierało, ale także organizację podważającą instytucję monarchii "wspartej na ołtarzu" . Także w państwach protestanckich działalność wolnomularstwa wywoływała sprzeciw z podobnych względów, tu jednak łączyło się to $\mathrm{z}$ obawą przed rekatolicyzacją ${ }^{10}$. Ważnym powodem potępiania masonerii była również budząca podejrzenia „sekretna działalność jej członków i składanie przez nich przysięgi o niewyjawianiu informacji na temat wewnętrznej struktury wolnomularstwa i jego partykularnych celów pod groźbą surowych kar"11.

Hierarchowie Kościoła katolickiego już w latach 30. wieku XVIII kilkukrotnie potępiali działanie tego stowarzyszenia. Głos w jego sprawie zabierali zdecydowanie kolejni papieże - jako pierwszy rzucił anatemę na wolnomularstwo Klemens XII w konstytucji apostolskiej „In eminenti”, ogłoszonej 28 kwietnia 1738 roku. W dokumencie tym zabronił katolikom przynależności do lóż masońskich opisywanych jako zagrożenie dla jedności Kościoła i stabilności poszczególnych państw ${ }^{12}$. Zarzuty te rozwinął potem Benedykt XIV w encyklice „Providas” z 1751 roku, w której wyliczał następujące przyczyny potępienia wolnomularstwa przez swego poprzednika:

1) międzywyznaniowość masonów; 2) tajemnica otaczająca organizację; 3) przysięga obowiązująca członków; 4) ich opozycja wobec Kościoła i państwa; 5) interdykt nałożony na nich w kilku państwach przez przywódców tych krajów; oraz 6) ich brak moralności, w ten sposób scharakteryzowany przez Papieża: „Te organizacje, według opinii rozważnych i uczciwych ludzi, mają złą sławę i członkostwo w nich prowadziłoby do zła i deprawacji”'13.

${ }^{8}$ Kwestia indyferentyzmu była szczegółowo omawiana przede wszystkim w XIX-wiecznych dokumentach papieskich oraz publikacjach teologicznych, zob. Tylka 1900, s. 45, por. Rostworowski 1984, s. 426-427; Kwiatkowski 2016, s. 74.

${ }^{9}$ Rostworowski 1984, s. 196.

${ }^{10}$ Lęk przed przywróceniem katolicyzmu dostrzegalny był zwłaszcza w Anglii, gdzie przyczynił się do wybuchu „chwalebnej rewolucji”, zob. Davies 1999, s. 675-676. Skądinąd niektóre loże wolnomularskie tak zwanej masonerii jakobickiej rzeczywiście do dążyły tego celu - zob. Cegielski 1992b, s. $46-47$.

${ }^{11}$ Kwiatkowski 2016, s. 66.

12 Bulla „In eminenti” uznawana jest obok encykliki „Humanum genus” Leona XIII za jeden z najważniejszych dokumentów skierowanych przeciwko wolnomularstwu, Suchecki 2008, s. 22-23. Bardzo duży nacisk na podkreślanie ich doniosłości kładą autorzy sceptycznie nastawieni wobec masonerii, zob. Pelczar 1914.

${ }^{13}$ Jouin 2019. 
Jednocześnie działania przeciwko masonerii podejmowały władze poszczególnych państw europejskich ${ }^{14}$. Zwykle jednak antymasońskie ustawy w ogóle nie wchodziły w życie, lub też przestawały obowiązywać po krótkim czasie.

Przedstawiciele wolnomularstwa odpowiadali na skierowaną przeciw nim działalność i podejmowali polemikę $\mathrm{z}$ antymasońskimi dokumentami i pismami ${ }^{15}$ w licznych publikacjach. Intencje polemiczno-obronne odnaleźć można między innymi w "Le franc-maçon prisonnier”, dramacie do czytania sygnowanym we francuskim wydaniu przez Hansa Heinricha Freiherra von Eckera und Eckhoffena. Sztuka napisana została w dwóch wersjach: francuskiej i niemieckiej. Ponieważ o rok wcześniej wydano francuską, pierwodruk przyjęto tu za podstawę dalszej analizy sztuki (jakkolwiek niewykluczone, że podstawą mógł być obszerniejszy a opublikowany później tekst niemiecki zatytułowany „Der Freymaurer im Gefängnis", który funkcjonuje pod imieniem Hansa Karla Freiherra von Eckera und Eckhoffena, młodszego brata wymienionego Hansa Heinricha) ${ }^{16}$.

Przed przejściem do prezentacji dramatu warto poświęcić choć kilka słów autorowi pierwotnej wersji dramatu. Niemiecki literat i wolnomularz Hans Heinrich Freiherr von Ecker und Eckhoffen urodził się w 1750 roku w arystokratycznej rodzinie, której korzenie sięgają co najmniej XVI wieku ${ }^{17}$. Najwcześniejszy znany no-

14 „Za negatywną reakcją katolików podążyły Stany Generalne Niderlandów, oficjalnie potępiając masonerię w 1735 r. Do nich dołączył Kanton Genewy w 1736 r., następnie Francja i książę elektor Palatynatu Manheim w 1737 r., magistrat miast Hamburg i król Szwedzki Fryderyk I w 1738 r., austriacka cesarzowa Maria Teresa w 1743 r., władze w Awinionie, Paryżu i Genewy, konsystorz (Consistory Council) miasta Hanower, kanton Berna i szef paryskiej policji w 1745 r., Wielki Sułtan Konstantynopola w 1748 r., Król Neapolu Karol VII (przyszły Karol III Hiszpański) i jego brat Ferdynand VI Hiszpański w 1751 r., magistrat w Danzing w 1763 r., gubernator Madery, władze Genewy i Brna w 1770 r., książe Monako i Karol Teodor Wittelsbach, elektor bawarski w 1784 r., wielki książę Badenii i cesarz Józef II Habsburg w 1785 r., cesarz Franciszek II Habsburg, król Sardynii Wiktor Amadeo i car Paweł I Romanow w 1794 r., Fryderyk Wilhelm III Pruski w 1798 r., by wymienić jedynie najbardziej znane przykłady", Kwiatkowski 2016, s. 66, por. Wójtowicz, 2014, s. 11.

${ }^{15}$ W latach 70. XVIII wieku głównymi przeciwnikami wolnomularstwa byli właśnie antymasońscy publicyści, np. Philippe Louis Gérard, o którym będzie mowa w dalszej części artykułu.

${ }^{16}$ Nie wchodzimy tu w skomplikowane kwestie autorstwa „Le Franc-maçon prisonnier” i „Der Freymaurer im Gefängnis” (rzeczywista braterska spółka autorska czy strategiczny kamuflaż?) ani problemy tekstologiczne (podstawa i warianty? Czy może przekład rozszerzony albo jednak dwa utwory na tyle różne, że można byłoby je uznać za oryginalne?). Zauważmy jedynie, że niemiecki tekst jest znacznie dłuższy, gdyż w toku akcji pojawia się większa liczba postaci i siłą rzeczy tekst rozbudowuje zależności w świecie przedstawionym i uzasadnienia działań oraz sytuacji dramatycznych. Wersja francuska natomiast nosi cechy „agitki” - zachowała bowiem wszystkie dłuższe dialogi, w których uwięziony wolny mularz przekonuje swych rozmówców o swej niewinności, co dodatkowo uzasadnia przyjęcie jej właśnie za podstawę prezentowanej analizy - por. von Ecker und Eckhoffen 1778.

17 Von Zeidlitz-Neukirch 1839, s. 142. 
bilitowany przedstawiciel, Wenzel (Wacław) von Ecker und Eckhoffen, miał mieć pochodzenie czeskie i przyjść na świat w Opolu w roku 1539 (jego rodzice to Michael i Regina), a umrzeć 24 lutego 1611 roku we Wrocławiu ${ }^{18}$. Z zachowanych do dziś publikacji niewiele jednak wiadomo o dalszych losach rodziny von Eckerów und Eckhoffenów, której najbardziej znanymi przedstawicielami są niezaprzeczalnie bracia Hans Heinrich i Hans Karl ${ }^{19}$.

Podobnie jak historia rodzinna, tak dzieje samego Hansa Heinricha (ur. 1 VIII 1750, zm. 14 VIII 1790) nie doczekały się jeszcze gruntownego opracowania. O ile na podstawie XIX-wiecznych życiorysów w leksykonach literaturoznawczych ${ }^{20}$ można stwierdzić, że jego młodszy brat jest autorem co najmniej dwunastu dzieł o charakterze literackim lub historycznym, a także licznych przekładów, między innymi tłumaczenia "Monachomachii” na język niemiecki ${ }^{21}$, to literacka działalność twórcy francuskojęzycznej dramy „Le franc-maçon prisonnier” pozostaje kwestią dość problematyczną. Wiadomo jednak, że poza jedyną sztuką ma na swym koncie kilka publikacji o charakterze masońskim ${ }^{22}$, a także interesujący pod względem treści podręcznik sztuki wojskowej pod tytułem „L’erudition universelle militaire ou analyse abrégée de toutes les sciences et parties militaires". Ponadto katalog Bibliothèque Nationale Française wskazuje go również jako autora broszury, której treść dotyczy postaci Stanisława Leszczyńskiego (znana jest jedynie w języku niderlandzkim ${ }^{23}$.

Wobec tak skromnego zasobu informacji o autorze dramy Le „franc-maçon prisonnier" warto w celu dogłębniejszego poznania jego poglądów omówić choćby ogólnie jego najbardziej obszerne dzieło, jakim jest „Lerudition universelle militaire ou analyse abrégée de toutes les sciences et parties militaires”. Patrząc na sam tytuł w bibliotecznym katalogu, można stwierdzić, że jest to kolejny, typowy podręcznik sztuki wojennej, jakich mnóstwo było w wieku XVII i XVIII; jednak

18 Sinapio 1728 , s. 604.

19 Hans Karl Freiherr von Ecker und Eckhoffen (ur. 26 VIII 1754, zm. 22 VI 1809) podobnie, jak starszy brat był wolnomularzem i literatem, znanym między innymi z przetłumaczenia na język niemiecki „Monachomachii” Ignacego Krasickiego; zob. Jäck 1812, t. 2, s. 237-238; Klimowicz 1998, s. 131; Piszczykowski 1969, s. 243.

20 Żywoty braci von Eckerów und Eckhoffenów w kontekście ich roli w lożach wolnomularskich opisane są także w „Enzyklopädie der Freimaurerei Lenninga oraz Internationales Freimaurer-Lexikon”, zob. Lenning 1822 s. 116-117, Lenhoff, Posner 1932, s. 241.

21 Von Zeidlitz-Neukirch 1839, s. 142.

22 „Der Rosenkreutzer in seiner Blösse zum Nutzen der Staaten hingestellt”; “De vry-metzelaar gevangene van staat”; por. [online]: <http://data.bnf.fr/documents-by-rdt/13005895/70/page1>.

23 „De Vlucht van Stanislaus Lescinzkij, koning van Poolen, tooneelspel (gevolgd naar het fransche van den heere J.H. baron Ecker de Eckhof), door het dichtlievend kunstgenootschap onder de spreuk: door oeffening wordt veel verkreegen"; por. [online]: <http://data.bnf.fr/13005895/hans_ heinrich_von_ecker_und_eckhoffen/>. 
po otwarciu książki okazuje się, że jest inaczej. Już na stronie tytułowej dostrzegamy bowiem motto - znany jako hasło rewolucyjne w Europie (tzw. starego ładu) cytat $\mathrm{z}$ „Meropy” Woltera: „Le premier qui fut Roi, fut un Soldat heureux” (pl. Pierwszy, który był królem, był [najpierw] żołnierzem szczęśliwym [dla kraju, tj. jego obrońcą]), zgodnie z którym prawo do sprawowania władzy nie musi wynikać $\mathrm{z}$ sukcesji, ale może $\mathrm{z}$ własnych zasług sięgającego po nią czy też nią obdarzonego $^{24}$. Pierwszy rozdział dzieła stanowi zbiór rad dotyczących urządzenia państwa, jakich udziela on rządzącym, spisując je w celu "nowego zjednoczenia wszystkich nauk z elementami sztuki wojskowej" ${ }^{25}$. Są one bardzo głęboko zakorzenione w ideach oświeceniowych, w szczególności w idei równości i sekularyzmu.

Tak więc zdaniem autora zarówno władca, jak i jego poddani mają swoje obowiązki w państwie. Ich wypełnianie prowadzi do powszechnej szczęśliwości i do-

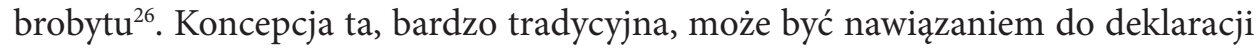
króla pruskiego Fryderyka II Wielkiego, który twierdził, że jest jedynie pierwszym sługą państwa, co różniło go np. od Ludwika XIV i jego następców, wobec czego wydaje się, iż stanowi ona apologię systemu panującego w Prusach.

Ważne przy tym według von Eckera und Eckhoffena jest rozdzielenie sfer religii i sprawiedliwości ${ }^{27}$. Stanowi to dowód na to, że jego dzieło napisane jest w duchu oświecenia, a przy tym jest nawiązaniem do filozofii Monteskiusza, który odróżniał cnotę w ujęciu religijnym od cnoty politycznej:

Dla zrozumienia pierwszych czterech ksiąg tego dzieła trzeba pamiętać, iż to, co nazywam w republice cnotą, jest to miłość do ojczyzny, inaczej miłość równości. Nie jest to cnota moralna, ani cnota chrześcijańska; jest to cnota polityczna; ona jest sprężyną rządu republikańskiego.

(...) Wreszcie zacny człowiek, o którym jest mowa w księdze III, rozdz. 5, nie jest to zacny człowiek w rozumieniu chrześcijańskim, ale w rozumieniu politycznym, posiadający cnotę polityczną, o której mówiłem ${ }^{28}$.

Zarówno pogląd o oderwaniu prawa do sprawowania władzy od dziedziczenia oraz sprawiedliwości od moralności religijnej był szeroko dyskutowany w kręgach wolnomularskich, do których należeli obaj bracia von Ecker und Eckhoffen ${ }^{29}$, wobec czego „L’erudition universelle militaire” może zostać odczytana również jako

24 Goulborne 2009, s. 100.

25 Von Ecker und Eckhoffen 1781, s. 1.

26 Ibidem, s. 1-2.

27 Ibidem, s. 3.

28 de Secondat de Montesquieu 2016, s. 5.

29 Na temat przynależności von Eckerów und Eckhoffenów do poszczególnych lóż zob. Lenhoff, Posner 1932, s. 241, Lenning 1822, s. 116-117. 
manifest popularnych wśród masonów koncepcji związanych ze sprawowaniem władzy ${ }^{30}$.

Dalsza część podręcznika von Eckera und Eckhoffena ma charakter bardziej praktyczny i skierowany głównie do wojskowych. Niezależnie od tego omówiony tu swego rodzaju manifest światopoglądowy trafiający do czytelnika już z pierwszych stron książki zasługuje na uwagę, gdyż w jego świetle stosunkowo mało znany Hans Heinrich von Ecker und Eckhoffen jawi się jako jeden z myślicieli politycznych postulujących sprawowanie władzy w duchu oświecenia.

Obok działalności literackiej drugim niezwykle ważnym elementem życiorysu Hansa Heinricha von Eckera und Eckhoffena jest wspomniana już działalność w lożach wolnomularskich. Zasługuje ona na uwagę przynajmniej z jednego powodu - von Ecker und Eckhoffen jest jednym z twórców masońskiego rytu wyższych stopni nazywanego Die Ritter des Lichts (Rycerze Światła), a w późniejszym okresie Die Bruder St. Johannes des Evangelisten aus Asien und Europa (Bractwo Świętego Jana Ewangelisty z Azji i Europy) ${ }^{31}$. Było to pierwsze masońskie ugrupowanie przyjmujące na tych samych zasadach chrześcijan i żydów ${ }^{32}$.

Wydaje się zatem, że jak działalność społeczna von Eckera und Eckhoffena podyktowana była chęcią realizacji idei charakterystycznych dla wolnomularstwa, tak literacką motywowała potrzeba ich popularyzacji; potwierdza to lektura „Le Franc-maçon prisonnier”, jego jedynego utworu dramatycznego. Drama stanowi odpowiedź na liczne w drugiej połowie XVIII wieku antymasońskie wystąpienia filozofów krytycznych wobec oświecenia oraz na powstawanie kolejnych dotyczących tej organizacji teorii spiskowych, według których masoni byli twórcami ogólnoeuropejskiego sprzysiężenia mającego na celu detronizację prawowitych władców. Tezy takie przedstawiało wielu myślicieli i pisarzy. Na największą uwagę spośród nich zasługują Philippe Louis Gérard, autor bardzo popularnej powieści pod tytułem „Le comte de Valmont, ou Les égarements de la raison” oraz tworzący w czasach rewolucji francuskiej Augustin Barruel.

Omawiana drama ma na celu obronę wolnomularstwa przed najczęściej powtarzanymi wobec niego zarzutami, co jest widoczne już w wyborze motta, za które przyjął von Ecker und Eckhoffen wersy tetrastychu autorstwa masona Ricauta, pochodzące $\mathrm{z}$ roku 1737, kiedy to za sprawą angielskiej aktorki, znanej jako madame Carton, doszło do ujawnienia wolnomularskich rytuałów ${ }^{33}$ :

${ }^{30} \mathrm{~W}$ podobny sposób można zresztą odczytywać również wiele innych traktatów politycznych oraz dzieł literackich i scenicznych powstałych w drugiej połowie XVIII wieku, między innymi mający swą premierę w 1791, „Czarodziejski flet” Wolfganga Amadeusza Mozarta z librettem Emanuela Schikanedera, zob. Notkowska 2007-2008, s. 117-127.

${ }^{31}$ Lenhoff, Posner 1932, s. 90 i 241, Lenning 1822 s. 23-25, 116-117, Mirabeau 1789, s. 106

32 Maciejko 2011, s. 225, Lenhoff, Posner 1932, s. 241.

${ }^{33}$ To zdarzenie było inspiracją dla francuskiego dramaturga Pierre’a Clementa do napisania sztuki pt. „Les Fri-maçons”, zob. Lantoine 1919, s. 36-37 i 42. 
Dla społeczeństwa wolny mularz

Będzie zawsze wielkim problemem,

Jeśli nie pozna [ono] tego, co w głębi,

Jeśli nie stanie się [samo] wolnym mularzem ${ }^{34}$.

Jednocześnie motto może wskazywać na to, że sztukę da się odczytać jako głos w mającym miejsce w latach 70. XVIII wieku konflikcie o kształt samego wolnomularstwa, wywołanym przez Karla von Hunda und Altengrotkau, który postulował przekształcenie masonerii $\mathrm{w}$ organizację wzorowaną na zakonie templariuszy ${ }^{35}$, w której ogromną wagę miano przykładać do bezwzględnego posłuszeństwa jej członków ${ }^{36}$. Jednocześnie w lożach, które zreformowano zgodnie z założeniami Karla von Hunda und Altengrotkau, zakładano zamknięcie dostępu do urzędów lożowych przed przedstawicielami niższych warstw społecznych, co stanowiło zaprzeczenie idei równości ${ }^{37}$. Dramat w tym kontekście można odczytać jako obronę klasycznych ideałów wolnomularskich i egalitaryzmu tej organizacji, której idee może zrozumieć, i przyjąć za swoje każdy, a nie tylko przedstawiciel elity ${ }^{38}$.

Akcja sztuki toczy się w jednym z państw, w których władze prześladowały masonerię. Nazwiska bohaterów wskazują na to, że jest to któreś z państw iberyjskich. Sytuacja, w której poznajemy głównego bohatera sztuki, markiza des las Casasa, nawiązuje do rzeczywistego położenia masonów w Portugalii w latach 40. XVIII wieku, kiedy to twórca tamtejszej loży Szkot John Coustos został uwięziony przez władze za działalność antypaństwową ${ }^{39}$. Ta łatwa do odczytania aluzja wskazuje na to, że sztuka ma na celu ukazanie niesprawiedliwości, jakich wolnomularze w przeszłości doświadczyli od rządów.

Drugim ważnym nawiązaniem ideowym i literackim dostrzegalnym już w warstwie nazewnictwa jest nazwisko głównego bohatera - des las Casasa, którego brzmienie przywołuje skojarzenie XVI-wiecznego hiszpańskiego dominikanina - wielkiego obrońcy indian podbijanych przez konkwistadorów. Nieco przed

${ }^{34}$ Anonim 1748, s. 3. Imię autora nieznane, w zbiorach pieśni masońskich opisywany był zawsze jako f[rère] lub monsieur. Tłumaczenie własne, utwór nie był wcześniej przekładany na język polski; datacja na podstawie: Guy 1974, s. 17.

${ }^{35} \mathrm{~W}$ kręgach związanych z wolnomularstwem ścisłej obserwy templariuszowskiej (gdyż tak nazywano ryt masoński powstały na gruncie idei Karla von Hunda und Altengrotkau) mówiło się wręcz o odtworzeniu zakonu templariuszy i podkreślano rolę monarchii francuskiej w dziele jego zniszczenia, co stało się pożywką dla kolejnych twórców teorii spiskowych, zob. Cegielski 1992a, s. 15.

36 Schwartz 2006, s. 244-245.

${ }^{37}$ Cegielski 1992a, s. 15-16.

${ }^{38}$ Cegielski 1992a, s. 15-16, Lenning 1824, s. 79-81. Sprzeciwiał się mu między innymi Lessing, Hass 1982, s. 148. Sprzeciw wobec stowarzyszenia, które stawiało w centrum swoich zainteresowań templariuszy, może być jednym z powodów, dla których jednym z antagonistów w „Natanie mędrcu” jest wielki mistrz tego zakonu.

${ }^{39}$ W późniejszym czasie spisał swe wspomnienia; zob. Coustos 1746. 
powstaniem sztuki von Eckera und Eckhoffena ów duchowny stał się bohaterem powieści Marmontela pod tytułem „Les Incas” (polskie tłumaczenie dokonane przez Stanisława Kłokockiego zostało wydane w roku 1781 i nosi tytuł „Inkasy”"40). Jak opisywał autor we wstępie:

Celem (...) dzieła tego, wyznaję szczerze, jest przyczynić się, ile możności do coraz większego obrzydzenia niszczącego fanatyzmu przeszkodzić, iżby nigdy go nie mieszano z religią pobłażającą i litościwą, a natchnąć ku niej tyleż poszanowania i miłości, ile nienawiści i obrzydzenia ku jej najokrutniejszemu nieprzyjacielowi ${ }^{41}$.

Współbrzmienie nazwisk bohaterów może zatem wskazywać na to, że tak jak historyczny i powieściowy de las Casas bronił niewinnych Indian, tak des las Casas broni masonów, którym także nie można niczego zarzucić.

Głównego bohatera sztuki poznajemy w więzieniu, w trakcie prowadzonego przeciwko niemu procesu. Jest on przesłuchiwany przez samego prokuratora generalnego, który w sposób niezwykle gorliwy wypełnia królewskie rozkazy dotyczące wolnomularzy. Za uwięzionym próbuje się wstawić najpierw minister stanu (scena pierwsza), a potem opat (scena trzecia). Żaden z nich prawdopodobnie nie jest członkiem tajnych stowarzyszeń, ale obydwaj po prostu nie odnajdują w uwięzionym żadnej winy lub też uznają kwestię wolnomularstwa za bardziej skomplikowaną.

Prokurator, będąc jednak człowiekiem w zupełności oddanym królowi i papieżowi, którzy nakazali rozpoczęcie prześladowania masonów, nie dostrzega możliwości popełnienia przez nich błędu i co więcej - daje wiarę oskarżycielom masonów, czego najdobitniejszym świadectwem jest jego monolog (mający miejsce po rozmowie z ministrem stanu), w którym padają następujące słowa:

Wydaje mi się, że głos ministra nosi wielką obroną tego nieszczęśnika. Rozumiem to. Markiz jest oczywiście dobry i ludzki. Wyrok śmierci wydany na jakichkolwiek przestępcę może sprawić smutek wszystkim na cały dzień. Jednak skąd ta poniżająca dobroć? (...) Wolni mularze - ludzie zuchwali i niegodziwi - mają wpływ na cały przebieg tego procesu. Trzeba, by zakończył się on dzisiaj. Król tego chce ${ }^{42}$.

W oczach prokuratora, który dąży do wypełnienia swych obowiązków wobec króla i Kościoła, każdy zatem jest potencjalnym oskarżonym. W sztuce jednak poza słowami urzędnika nie ma żadnych dowodów na to, że minister stanu czy

${ }^{40}$ Dzieło na terenie Polski dzieło zdobyło dużą popularność i było wznawiane w roku 1794 i 1801, zob. Frydrychowicz 1959, s. 301.

${ }^{41}$ Marmontel 1794, 1, s. XXXII.

${ }^{42}$ Von Ecker und Eckhoffen 1777, s. 6 (tłumaczenie własne, utwór nie był dotąd tłumaczony na język polski). 
opat są masonami; a wiedza o ich przynależności do loży miałaby pewien wpływ na sposób interpretacji: sztuka mianowicie stałaby się jednocześnie masońskim moralitetem, pokazującym, jak powinno postępować się wobec braci, których dotknęła bieda. Natomiast przy założeniu, że postaci te nie są masonami, dostrzegalny jest po prostu przekaz, że w rzeczywistości wszelkie negatywne działania wobec wolnomularzy są wynikiem jedynie złej woli ich wrogów. Drama jest niejednoznaczna w tej kwestii, czego przykładem może być m.in. monolog opata, znajdujący się w scenie piątej, w którym duchowny zastanawia się nad tym, co powinien zrobić, by uczynić zadość zarówno swym obowiązkom, jak i królewskim rozkazom. Obowiązkom - wobec brata, czy też może wobec religii i wypływającym $\mathrm{z}$ niej nakazów? W kontekście motta utworu odpowiedzią rozstrzygającą dylemat jest druga ze wskazanych możliwości, gdyż w kwestiach sprawiedliwości i podejścia do bliźniego chrześcijaństwo i masoneria są bardzo do siebie zbliżone i opat zapewne to zauważa, uznając przy tym więźnia za człowieka niewinnego, któremu nie sposób zarzucić jakąkolwiek niegodziwość. Minister stanu i opat zatem odnajdują wolnomularza (jak zaleca motto) w samych sobie.

W scenie szóstej opat odwiedza więźnia, by po raz kolejny chwilę z nim porozmawiać. Relacje między nim i uwięzionym masonem są pozytywne, obecność opata jest dla więźnia pocieszeniem $\mathrm{w}$ niedoli ${ }^{43}$. Z kolei opat, który na początku swej wizyty u oskarżonego zaznacza, że nie przychodzi do niego $\mathrm{z}$ własnej woli, ale z woli króla (czyżby władca przewidywał, że jego prokurator może być nadgorliwy?), sugeruje, że źródłem nieszczęść uwięzionego wolnomularza są znane mu tajemnice. Jest to zatem element upodabniający „Le Franc-maçon prisonnier” do opery „Les Franches-maçonnes”, jednak w libretcie Poinsineta „martyrologia” masonów jest czymś komicznym, gdyż cierpieniem, jakie na nich spada, jest zamknięcie przez ciekawskie kobiety w budynku loży ${ }^{44}$. Tu natomiast zagrożenie, jakie dosięga des las Casasa, jest o wiele poważniejsze. Na koniec rozmowy, do której dołącza także adwokat, opat obiecuje des las Casasowi, że opisze jego sprawę królowi ${ }^{45}$.

Jednak zanim sytuacja więźnia się wyjaśni, po raz kolejny przychodzi do niego prokurator. Na początku próbuje ponownie namówić des las Casasa do wyznania wszystkich masońskich „przestępstw i tajemnic”, jednak on przecież żadnych przestępstw nie popełnił, wobec czego próbuje bronić się przed kolejnymi zarzutami urzędnika. Gdy prokurator w pierwszej kolejności porusza sprawę religii, zarzucanych masonom bluźnierstw oraz podważania królewskiej władzy, uwięziony wol-

${ }^{43}$ Ibidem, s. 10.

${ }^{44}$ Clavel 1846, s. 94, Motyw niemogących zostać wolnomularzami kobiet pragnących poznać masońskie sekrety jest niezwykle częsty w dramatach, w których pojawia się bohater-wolnomularz, zob. Clement 1740, Kotzebue 1819, por. Lantoine 1919.

${ }^{45}$ von Ecker und Eckhoffen 1777, s. 16. 
nomularz odpowiada, że masoneria przecież w najmniejszym stopniu nie zwalcza religii, co więcej - nie można zostać wolnomularzem, jeżeli nie wyznaje się „religii przodków" ${ }^{36}$, a przy tym masoneria nie narusza w żaden sposób istnienia tradycyjnie pojmowanego państwa i władzy, gdyż zaleca się braciom, by byli dobrymi obywatelami i wiernymi poddanymi ${ }^{47}$. W ten sposób usiłuje przekonać prokuratora, że w rzeczywistości wolnomularstwo w żaden sposób nie przeciwstawia się ani religii, ani moralności, ani porządkowi społecznemu.

Niezwykle interesujące jest ustosunkowanie się des las Casasa wobec kolejnego argumentu prokuratora, czyli ciążącej nad masonami klątwy. Uwięziony wolnomularz w odpowiedzi bowiem stwierdza, że nawet najmądrzejszy z ludzi może popełnić błąd ${ }^{48}$. Twierdzenie to było niezwykle aktualne w latach 60. i 70. XVIII wieku, kiedy prowadzono ożywioną dyskusję na temat niektórych papieskich decyzji, na przykład rozwiązania zakonu jezuitów, które uznawane było za przejaw uległości władzy kościelnej wobec władzy świeckiej; zatem argument ten potencjalnie mógłby trafić nawet do ludzi bardzo religijnych.

W dalszej części przesłuchania prokurator zadaje pytanie o zasady postępowania obowiązujące masonów. Des las Casas w odpowiedzi na nie, posługując się odwołaniami do wolnomularskich pieśni ${ }^{49}$, wymienia obowiązki, jakie stoją przed członkiem zgromadzenia, a także dokonuje charakterystyki dobrego wolnomularza: "Wolny mularz to dobry i cnotliwy obywatel, poddany przepełniony wiarą i wiernością wobec swego króla, państwa, a w szczególności wobec swych przyjaciół" ${ }^{50}$. Twierdzenie to jest niezwykle bliskie poglądom innych wolnomularzy bohaterów sztuk teatralnych (np. „Les Fri-maçon” Pierrea Clementa ${ }^{51}$ i „Wolny Mularz" Augusta von Kotzebuego ${ }^{52}$ ). Można stwierdzić, że jego pojawienie się $\mathrm{w}$ wypowiedzi bohatera dramatu ma wskazywać na pozytywny stosunek do sekretnego stowarzyszenia von Eckera und Eckhoffena, a także autorów tych popularnych wówczas dramatów. Prokurator jednak nadal zupełnie nie rozumie, co $\mathrm{w}$ takim razie wolnomularze ukrywają przed światem; zadaje pytanie o to des las Casasowi, a ten odpowiada, że w centrum masońskich ideałów są równość oraz szacunek, wynikające ze starożytnej mądrości, która im przyświeca. Następnie wolny mularz spokojnie reaguje na wiadomość o tym, że może zostać skazany nawet na śmierć. Robi to zapewne wrażenie na prokuratorze, który mimo to pozostawia uwięzionego w niepewności, żegnając go słowami: „Myślę, że zbliża się

\footnotetext{
${ }^{46}$ Ibidem, s. 19.

47 Ibidem, s. 19.

${ }^{48}$ Ibidem, s. 20.

${ }^{49}$ Por. anonim 5768 [właść. 1768], s. 102; anonim 1772, s. 136.

${ }^{50}$ Von Ecker und Eckhoffen, 1777, s. 22.

${ }^{51}$ Clement 1740.

${ }^{52}$ Von Kotzebue 1819.
} 
koniec twoich cierpień" ${ }^{33}$. Des las Casas nie rozumie ich dwuznaczności. Mniema, że zostanie skazany na śmierć. Oczekując na decyzję w swojej sprawie, nie zastanawia się nad swoim losem, ale postanawia wybaczyć swym prześladowcom, choć ma do nich wielki żal o kalumnie, jakimi obrzucają organizację, do której należy ${ }^{54}$.

Po chwili do des las Casasa przychodzi oficer, który przekazuje mu informację o tym, że jego sprawa zostanie rozstrzygnięta już dzisiaj, a następnie podejmuje krótką rozmowę, podczas której próbuje wpłynąć na niego, by zrezygnował ze swoich poglądów i przynależności do tajnego stowarzyszenia, gdyż nie przyniosło to w jego życiu żadnych pozytywnych skutków. Ten jednak przekonuje, że w trudnościach poznaje samego siebie i zaczyna lepiej się rozumieć, a następnie opowiada o wzajemnych relacjach braci między sobą. Oficer, podobnie jak wcześniejsi rozmówcy wolnego mularza, jest pod wrażeniem, jednak, jak przyznaje, nie rozumie sposobu myślenia prezentowanego przez więźnia ${ }^{55}$. Dialog uwięzionego masona $\mathrm{z}$ oficerem pełni w sztuce bardzo ważną rolę, gdyż odbiorcy przynosi odpowiedź na pytanie, po co te wszystkie sekrety, a jest ona prosta. Wolnomularze mają tajemnice, ponieważ większość ludzi z zewnątrz i tak niewiele zrozumie i nie podzieli przekonania o ważnych dla nich wartościach, jeżeli będzie poznawać je, nie będąc uprzednio ku temu przygotowanym. Zrozumienie okazane uwięzionemu wolnomularzowi przez oficera może być także odczytane jako głos sprzeciwu wobec wspomnianych już idei Karla von Hunda und Altengrotkau, postulującego elitaryzację wolnomularstwa.

Następuje chwila decydująca. Powraca prokurator, który przekazuje des las Casasowi radosną wieść - wolny mularz zostaje uwolniony, a przed wyjściem $\mathrm{z}$ więzienia rozmawia jeszcze $\mathrm{z}$ ministrem stanu, który oznajmia, że dzięki wynikowi procesu, w którym podsądny został uwolniony, ani wolnomularze, ani święci w niebie nie mogą mieć żadnych pretensji wobec niego [ministra] ${ }^{56}$. W pewnym sensie zatem przeprowadzenie procesu stanowiło dla markiza Blanville alibi, sposób uniknięcia problemów w stosunkach z Kościołem.

Nieszczęścia sprowadzone na des las Casasa przez władze państwa współdziałające z Kościołem mogły więc zostać potraktowane jako argument na rzecz rozłączenia religii, moralności i prawa, czego wielkimi zwolennikami byli bracia von Ecker und Eckhoffen (widoczne jest to między innymi w „Erudition militaire" autorstwa Hansa Heinricha). Jednocześnie postaci opata, prokuratora, ministra stanu i strażnika można odczytać jako obrazy różnych sposobów podejścia do wolnomularstwa. Prokurator jest wrogiem tej organizacji, gdyż uważa się on za

\footnotetext{
${ }^{53}$ Von Ecker und Eckhoffen 1777, s. 23.

${ }^{54}$ Ibidem, s. 23-24.

55 Ibidem, s. 25.

${ }^{56}$ Ibidem, s. 27.
} 
wykonawcę woli królewskiej i dlatego stara się wyciągnąć z więźnia jakiekolwiek zeznanie i przyczynić się do jego ukarania. Jednak król stojący ponad wszystkim, co się dzieje, nie pojawiając się na scenie, pod wpływem relacji opata, zmienia zdanie, w wyniku czego urzędnik musi zrobić to samo. Prokurator może zatem symbolizować tych, którzy z powodu ulegania autorytetom są wrogami sztuki królewskiej. Gdy te autorytety poznają się na niej, oni również będą musieli zmienić swe zdanie. Ukazana scena uwolnienia uwięzionego masona jest zatem odzwierciedleniem rzeczywistego położenia wolnomularstwa w latach 70. XVIII wieku, kiedy to nawet niektórzy monarchowie i duchowni byli członkami lóż i mogło się wydawać, że wrogie działania podejmowane przez elity kościelne i polityczne wobec masonerii należą już do przeszłości ${ }^{57}$.

Opat i minister stanu zapewne stopniowo podczas procesu przekonywali się do słuszności masońskich idei i na dodatek byli w stanie je zrozumieć, w przeciwieństwie do strażnika, który mimo, że podziwiał argumentację des las Casasa, nie rozumiał jej. Jednocześnie postaci opata i ministra stanowią obraz postawy religijnej i tolerancyjnej, a prokurator w swych działaniach ukazuje się jako gorliwy wykonawca woli królewskiej. Ponadto zauważyć można, że obydwie pozytywnie nastawione wobec uwięzionego wolnomularza postaci dostrzegają pewne podobieństwo między postrzeganiem świata swoim ukształtowanym przez religię, a światopoglądem więźnia, co miało stanowić dowód na prawdziwość motta sztuki.

Tak więc ewidentne jest tu przesłanie sztuki polegające na tym, że negatywne działania wobec masonerii wynikają ze złej woli, a jeżeli ktokolwiek pozna choćby w niewielkim stopniu wolnomularskie wartości, staje się ich obrońcą, a być może nawet zaczyna pałać pragnieniem wstąpienia do loży. Jednocześnie dzieło von Eckera und Eckhoffena poprzez nawiązania do „Inkasów” Marmontela może być traktowane jako manifest oświeceniowej tolerancji ${ }^{58}$, a postać wolnomularza jako obraz każdego człowieka prześladowanego ze względu na swój światopogląd. „Le Franc-maçon prisonnier" prawdopodobnie nie został nigdy zaprezentowany publiczności teatralnej. Był to jeden z wielu XVIII-wiecznych dramatów mających charakter raczej dydaktyczny niż artystyczny. Takie sztuki były wydawane i czytane, ale niekoniecznie inscenizowane $\mathrm{w}$ teatrze (pomimo wielu prób nie udało mi się dotrzeć do jakiegokolwiek dowodu na to, że sztuka von Eckera und Eckhoffena kiedykolwiek

${ }^{57}$ W latach 70. XVIII wieku aktywnymi wolnomularzami byli między innymi król Prus Fryderyk II Wielki i król Polski, Stanisław August Poniatowski, zob. Davies 1999, s. 679, Hass 1982, s. 69. Natomiast kwestią sporną jest przynależność do loży króla francuskiego Ludwika XVI i jego braci, Hass 1982, s. 89. Problemem w tym czasie stały się natomiast podejmowane przez monarchów próby podporządkowania sobie niektórych lóż, zob. Schwartz 2006, s. 237-246.

${ }^{58}$ Będącej skądinąd również jednym z głównych elementów tak zwanej antropologii wolnomularskiej, por. Stępień 2000, s. 132. 
została zrealizowana na scenie). W zasadzie zazwyczaj nawet bliżej im do dialogów filozoficznych niż do utworów dramatycznych ${ }^{59}$. Z uwagi na niewielką objętość można powziąć domniemanie, że „Le Franc-maçon prisonnier” czytany był podczas posiedzeń niektórych masońskich lóż. Na potwierdzenie tej tezy nie ma jednak zbyt wielu argumentów, jeśli zważyć, że wolnomularze podczas agape raczej śpiewali pieśni i kantaty, niż odczytywali sztuki teatralne. Fakt, że omówiony tu pokrótce dramat nie posiada zbyt rozbudowanej akcji i najpewniej nie był przedstawiany publicznie, skłania do wniosku, że jest on w gruncie rzeczy raczej rozprawą apolegetyczną i manifestem ideowym w kostiumie sztuki, a przy tym ważnym świadectwem światopoglądowych konfliktów, jakie miały miejsce w XVIII wieku.

\section{THE IMPRISONED FREEMASON, NATHAN THE WISE AND THE INCAS, OR A PIECE CONCERNING THE WORK OF A GERMAN BARON IN THE CONTEXT OF THE ENLIGHTENMENT CONCEPT OF TOLERANCE}

\section{Summary}

The work created by Hans Heinrich Freiherr von Ecker und Eckhoffen is an apology of Freemasonry - which made quite a contribution to the propagation of the Enlightenment - and the philosophy it advocated. The German aristocrat and Freemason introduces a noble, yet imprisoned Freemason, whose attitude and statements undermine any accusation levelled against the representatives of the royal art. He also speaks with regard to the internal conflict between them and, drawing on Marmontel's "Les Incas" - which were very popular at the time - makes his piece a manifesto of the Enlightenment idea of tolerance.

\section{Bibliografia}

Anonim 5768 [właść. 1768], Lyre maçonne ou Recueil choisi des plus jolies chansons, Jerozolima [właśc. Haga].

Anonim 1772, Recueil de chansons de la très-vénérable confrairie des francs-maçons, Jerozolima [właśc. Haga].

Anonim 1748, Recueil de poesies maçonnes, Jerusalem [właśc. Haga].

Cegielski T. 1992a, Ordo in chao. Wolnomularstwo wobec kryzysów oświeceniowej Europy, Ars regia, 1, s. 7-24.

Cegielski T. 1992b, Sekrety masonów. Pierwszy stopień wtajemniczenia, Warszawa.

Clavel F.-T.B. 1846, Almanach pittoresque de la Franc-maçonnerie, Paris.

Clement P. 1740, Les Fri-maçons, Londres.

Coustos J. 1746, The Sufferings of John Coustos, for Free-masonry, and for His Refusing to return to Roman Catholic, London.

Davies N. 1999, Europa. Rozprawa historyka z historią, Kraków.

${ }^{59}$ Np. „Alcibiade enfant” autorstwa Augusta Gottlieba Meißnera, wydany kilkukrotnie między rokiem 1789 a 1795, stanowi połączenie powieści historycznej, dramatu i dialogów filozoficznych. 
Ecker und Eckhoffen H.H. von 1781, L’erudition universelle militaire ou analyse abrégée de toutes les sciences et parties militaires, Augsbourg 1781.

Ecker und Eckhoffen H.H. von 1777, Le franc-maçon prisonnier, Paris.

Ecker und Eckhoffen H.K. von 1778, Der Freimaurer in Gefangnisse, Hamburg.

Frydrychowicz G. 1959, Stanisław Kłokocki. W kręgu Puław, Pamiętnik literacki, 3-4, s. 297-319.

Goulborne R. 2009, Voltaire's masks. Theatre and theatrality, [w:] The Cambridge Companion to Voltaire, red. N. Cronk, Cambridge.

Guy R. 1974, Gœthe, franc-maçon. La pensée et l'œuvre maçonniques de J.W. von Gœthe, Paris.

Hass L. 1982, Wolnomularstwo w Europie środkowo-wschodniej w XVIII i XIX wieku, Wrocław.

Jäck J.H. 1812, Pantheon der Literaten und Künstler Bambergs, Bamberg 1812.

Jouin E. 2019, Papiestwo i masoneria [online]. Ultramontes [dostęp: 2019-05-04]. Dostępny w Internecie: <http://www.ultramontes.pl/papiestwo_i_masoneria.htm>.

Klimowicz M. 1998, Polsko-niemieckie pogranicza literackie w XVIII wieku. Problemy uczestnictwa w dwu kulturach, Wrocław.

Kluge R.D., Świderska M. 2010, Zarys historii literatury i kultury niemieckiej, Łódź.

Kotzebue A. von 1819, Wolny mularz, przeł. K. Brodziński, Warszawa.

Kwiatkowski F. 2016, Stanowisko Watykanu wobec masonerii w XVIII w., Sensus Historiae, 2, 63-75.

Lantoine A. 1919, Les franc-maçons au théâtre, Paris.

Lenhoff E., Posner O. 1932, Internationales Freimaurer-Lexikon, Wien.

Lenning C. 1822, Encyclopädie der Freimaurerei, 1, Leipzig.

Lenning C. 1824, Encyclopädie der Freimaurerei, 2, Leipzig.

Lessing G. E. 1877, Natan mędrzec, przeł. A. Kwiryn, Warszawa.

Lindemann W. 1866, Geschiste der deutschen literature, Freiburg.

Locke J., List o tolerancji, przeł. L. Joachimowicz, przedm. R. Klibansky, wstęp E. de Marchi, Warszawa 1963.

Maciejko P. 2011, The Mixed Multitude. Jacob Frank and the Frankist Movement, 1755-1816, Philadelphia.

Majkowski W. 1998, Tolerancja i jej granice, Sympozjum, 2, s. 37-50.

Marmontel J.F. 1794, Inkasy, czyli zniszczenie państwa Peru, przeł. S. Kłokocki, Lwów.

Mirabeau H.B. Riqueti de 1789, Histoire secrète de la Cour de Berlin; ou, correspondance d'un voyageur. Essai sur la secte des Illumines, Paris.

Notkowska M. 2007/2008, “Czarodziejski flet”, czyli marzenie dwóch wolnomularzy o idealnym państwie, Ars regia 17, s. 117-127.

Pelczar J.S. 1914, Wolnomularstwo, Warszawa.

Piszczykowski M. 1969, Ignacy Krasicki. Monografia literacka, Kraków.

Rostworowski E. 1984, Historia powszechna. Wiek XVIII, Warszawa.

Schwartz W. 2006, Fryderyk Wielki i sztuka królewska, Ars regia 15-16, s. 237-249.

Secondat de Montesquieu Ch.L. de 2016, O duchu praw, przeł. T. Boy Żeleński, Kraków.

Siemieński L. 1876, Listy Stanisława Augusta do pani Geoffrin, opr. L. Siemieński, Kraków 1876.

Sinapio J. 1728, Schlesische Curiositäten, Leipzig und Breslau.

Stępień M.B. 2000, Poszukiwacze prawdy. Wolnomularstwo i jego tradycja, Lublin.

Szwed A. 2014, Johna Locke’a koncepcja tolerancji jako reakcja na zasadę "cuius regio, eius religio", Roczniki filozoficzne 4, s. 65-85.

Tylka J. 1900, Dogmatyka katolicka. Część ogólna, Tarnów. 
Wawrykowa M. 1993, Moses Mendelssohn. Przedstawiciel niemieckiego oświecenia i animator żydowskiej haskali, Przegląd humanistyczny 4, s. 19-24.

Wawrykowa M. 1989, U progu nowoczesności. Szkice z dziejów kultury niemieckiej XVIII i XIX wieku, Warszawa.

Wolter 1988, Traktat o tolerancji napisany z powodu śmierci Jana Calasa, przeł. Z. Ryłko i A. Sowiński, Warszawa.

Wójtowicz N. 2014, Wolnomularstwo a Kościół katolicki. Wrogowie, przeciwnicy, czy konkurenci?, Krzeszowice.

Zeidlitz-Neukirch L. von 1839, Neues preussisches Adels-Lexicon, Lepzig.

Zdziechowski M. 1938, W obliczu końca, Wilno. 